\title{
Energy Transition and Sustainable Development: Case of the Mohammed VI Football Complex
}

\section{Kharbouch Hassan*, Kaach Mohamed and Guedira Mohamed}

Faculty of Education Sciences, Mohamed V University, Morocco

*Corresponding Author: Kharbouch Hassan, Faculty of Education Sciences, Mohamed V University, Morocco.
Received: October 27, 2021

Published: November 26, 2021

(C) All rights are reserved by Kharbouch

Hassan., et al.

\begin{abstract}
The main objective of this article is to demonstrate the importance of the Moroccan Football Association's commitment through Moroccan companies to environmental protection and to present in this sense clear and concrete approaches in parallel with the realisation of economic efficiency.

We have opted for a qualitative analysis based on the literature review, which is based on information from several scientific studies and the Intergovernmental Panel on Climate Change (IPCC) synthesis Reports [17].

In this sense, this study proposes a decision-making approach to choose between the use of the fossil energy and the solar system in the Mohammed VI Football Complex, which is considered the most important football structure in the world.

The criteria we have set to justify and permit a choice of energy system are the calculation of costs and the measurement of the amount of $\mathrm{CO}_{2}$ emissions according to the two proposed solutions.

The results analysis has identified that the use of the solar system is the best solution in terms of economical criteria (lower cost), this project is profitable, with a return on the investment over 18 months. In terms of environmental criteria, the solution produces no gas emissions.

Finally, in the short term, the objective of the complex is to reach $100 \%$ sustainable energies. This will lead to energy certification and will make this structure the first green sports centre in the world.
\end{abstract}

Keywords: Sustainable Development; Energy Transition; Mohammed VI Football Complex

\section{Introduction}

Due to Climate Change, the world is more and more faced with urgent environmental issues. Several ecological questions, particularly concerning energy, are surfacing globally in a preoccupying manner and imposing on people's minds the need for an "energetic transition" as a solution. the necessity of behavioural changes for all human beings towards the different existing energy sources is imperative.
The Royal Moroccan Football Association's (FRMF) commitment to a sustainable development policy is today unavoidable.

Indeed, an environmental and social clause booklet has been integrated during the construction phase of the Mohammed VI Football Complex, for the preservation of the environment, it concerns the adoption of an ecological conduct since the construction site, by the application of good environmental practices of this sports structure. 
The concretisation of this commitment therefore leads us to carry out an in-depth reflection. The first step will be to define all the terms and concepts related to this article, in particular, sustainable development and sustainable energies.

\section{Literature}

Sustainable energies

Unlike fossil resources, renewable resources are continuously produced. Exploiting them means capturing a flow, not drawing on a stock. Sustainable development and energy issues. The issue of sustainable energies development is inseparable from that of sustainable development [1]. Emmanuelle Reynaud., et al. 2011.

The use of sustainable energies would make it possible to meet the energy needs of the current population, but also the needs of future generations.

Indeed, these energies are sustainable and their higher use will better ensure the sustainability of the planet's natural resources and of fossil fuels for future generations [2]. Laurence Lecoeur, 2010.

It will also prevent the depletion of natural resources with the necessary conditions for sustainable development. The definition of sustainable development also includes the conservation of the general equilibrium, the value of the natural patrimony.

Sustainable energies fit this bill perfectly, as they are clean, nonpolluting and do not produce greenhouse gases. It should be noted that producing electricity from sustainable energies contributes to the protection of the environment.

Hydroelectricity is now the most important commercial source of sustainable energies, representing more than $15 \%$ of the world electricity production [3]. Françoise Quairel-Lanoizelée, 2010.

The historical context of sustainable development in Morocco

By 2050, Morocco, like the rest of the world, will have to face the consequences of greenhouse gas (GHG) emissions, as well as temperature increases. Morocco has been conscious of the need to strengthen its commitment to sustainable development since the Rio Conference in 1993. This is because the use of natural resources is rationalised and the quality of life of citizens is continuously improved [4]. At the Johannesburg Summit on Sustainable
Development in September 2002, Morocco's participation marked its willingness to contribute to the integration of environmental standards into the definition of growth objectives.

Indeed, Morocco is a signatory to several international conventions related to sustainable development, including the protection of endangered species, pollution, protection of the ozone layer, maritime pollution.

On 20 September 2012, it signed the Environment Charter at the Energy Forum in Rabat his charter is the result of an environmental protection mechanism launched in 2010, on the occasion of the celebration of World Earth Day. Thus, the implementation of the national sustainable development strategy extends to 2030.

The most emblematic impact of fossil energy consumption is global warming, the reality of which is now widely acknowledged.

Since the beginning of temperature records in 1880, 2014 and 2015 have been the warmest years on earth [5]. $\mathrm{CO}_{2}$ emissions reached a record high in 2014 and the concentration of $\mathrm{CO}_{2}$ crossed the symbolic threshold of 400 PPM3 according to the World Meteorological Organisation (WMO). In France, for example, the building sector generated $20 \%$ of greenhouse gas (GHG) emissions in 2013 [6] compared to $16.3 \%$ in 2010) [7].

In the face of these considerations, as in the case of France, it was obliged to commit to reduce its GHG emissions by a factor of 4 under the Kyoto Treaty by 2050.

The Energy Transition Law was passed on 17 August 2015 in order to set concrete objectives in terms of greenhouse gas reduction, control of the share of nuclear power, production of sustainable energies and also highlighted the challenges of energy rehabilitation.

\section{Environmental analysis}

Synthesis of the environmental analysis

According to the Intergovernmental Panel on Climate Change (IPCC), Global warming is now clear from observations made over several decades [8]. Bertrand, F, 2010, unequivocal [9]. Bertrand., et al. 2012 due to the inertia effects of the atmospheric system. The quantities of greenhouse effect gases emitted to date induce in an inescapable way, and independently of the efforts made today [10]. 
Chalas, Y. and O. Soubeyran, 2010 a change in current climate conditions. Societies must, and will, henceforth adapt to it, to varying degrees depending on the territory (spatial variability) and the actual evolution of global changes (temporal variability).

Despite this observation of the need for change, action on climate change and the first climate policies at the territorial level are coming relatively late in the fight against climate change.

It was only after the agreement on quantified objectives [11]. Adger., et al. that the questions of how to act really came to the fore, recognising the importance of reducing greenhouse gas (GHG) emissions from human activities. It took 20 years since the first World Climate Conference in Geneva (1979) to see action plans being discussed [12]. Intergovernmental Panel on Climate Change 2007.

The main objective of this article would be to demonstrate the importance of the FRMF's commitment through Moroccan companies to environmental protection, and to present in this sense clear and concrete approaches in parallel with the realisation of economic efficiency.

Urban policies to move away from fossil energies are first of all circumscribed by fields of opportunity and constraints defined by national contexts: national energy resources). Laigle L., 2009. The environmental mobilisations of the 1960s and 1970s were a determining factor in laying the foundations in each of the European countries, depending on their environmental culture and orientations. In Germany, anti-nuclear mobilisations were the basis for the development of active civil societies, from which the Greens, who steer climate policies, emerged. In Sweden, the level of ambition of a territorial climate plan reflects above all a political will, which is often coupled with a desire for leadership [13]. Brohmann B., 2006.

The political piloting of energy production choices is evidently a decisive element of the urban energy transition. However, in many French cities, the possibilities for local authorities to reduce $\mathrm{CO}_{2}$ emissions are much more limited [14]. Scheer H., 2007. For heating, municipalities with a long history of extensive heating networks have been able to use bioenergy (wood waste and extensive use of organic waste) [15]. Laigle L, 2009.

The carbon tax in Sweden (1991) and then carbon quotas were decisive in getting district heating companies to make a more com- plete switch to biomass. These thermal regulations have made promoters and constructors more efficient and competitive in terms of ecobuilding.

This consumption is estimated to account for $40-50 \%$ of greenhouse gas emissions in the Netherlands, Sweden, the UK and Norway [16]. Jackson (2006).

Reducing them involves changes in production, consumption and living patterns - in other words, in development.

\section{Presentation of the problem}

This study concerns energy consumption, covered by the thermal regulations. Therefore, it was necessary to choose the most reliable and economical solution to produce this energy.

Two solutions were proposed for the energy consumption by means of gas boilers or air/water heat pumps such as DRV-hydro kit and solar thermal panels.

Which is the most reliable solution, among these two proposals? What is its impact on the environment? What is the most costeffective solution in terms of savings?

\section{Presentation of the structure}

Mohammed 6 Football Complex is under the authority of the FRMF. It was inaugurated in December 2019. It is spread over an area of 30 hectares and is one of the best sports centres in the world in terms of sports infrastructure and equipment. It hosts the activities of the national football teams and training courses.

This sports facility is committed to an energy transition approach with projects to control energy, production from sustainable energies. At the end of its three years of operation, it aims to achieve a significant reduction in fossil energy consumption.

An environmental impact study has been incorporated beforehand, through environmental clauses in the specifications of its construction and subject to urban planning as well as environmental policy. This eco-design study concerned the treatment, the recovery of wastewater through a purification station; the recovery of rainwater, even the roadway used is very reduced in this sports structure. The energy, the lighting system of the sports complex is provided by low consumption LEDs. They generate significant energy and financial savings and contribute to environmental protec- 
tion. On 48,000 square meters of constructed area. The facilities require a very large amount of energy for their operation. This need is estimated at $1540 \mathrm{KW}$ in total calorific power.

\section{Methodology}

This study concerns the energy consumption covered by the thermal regulations (lighting, heating, production of sanitary water, ventilation, cooling, etc.).

Therefore, it was necessary to choose the most reliable and economical solution to produce this energy. Two energy consumption solutions were proposed, one using gas boilers and the other using air/water heat pumps such as DRV-hydro kits and solar thermal panels.

- $\quad$ Solution 1: Gas boilers: Its installation requires boilers, gas tanks and chimneys.

- $\quad$ Solution 2: DRV-hydro kit type air/water heat pumps and solar thermal panels: This is a combined solution between the DRV-Hydro kit system which operates in winter or in periods of no sunshine and the solar thermal panels which operate in summer and in periods of sunshine.

The equipment required is DRV outdoor units, hydro kit indoor units and solar thermal panels.

\section{Results}

\begin{tabular}{|l|c|c|}
\hline & $\begin{array}{c}\text { Gas boiler } \\
\text { system }\end{array}$ & $\begin{array}{c}\text { Heat pump/solar } \\
\text { panel systems }\end{array}$ \\
\hline Annual $\mathrm{CO}_{2}$ emission $(\mathrm{kg})$ & 1.037 .190 & 0 \\
\hline
\end{tabular}

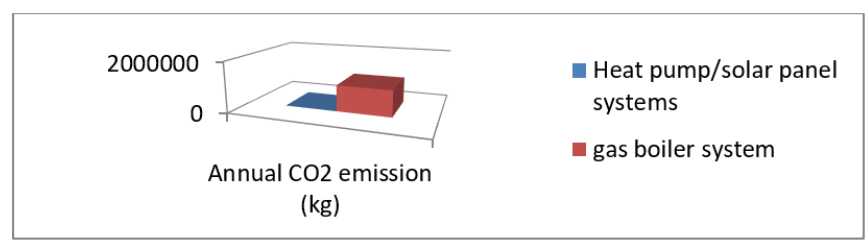

Table 1

\begin{tabular}{|c|c|c|c|c|}
\hline \multirow{2}{*}{$\begin{array}{l}\text { System used } \\
\begin{array}{l}\text { Gas boiler } \\
\text { system }\end{array}\end{array}$} & \multirow{2}{*}{$\begin{array}{c}\begin{array}{c}\text { Power } \\
\text { required } \\
\text { (KW) }\end{array} \\
1540\end{array}$} & \multicolumn{2}{|c|}{ Energy required } & \multirow{2}{*}{$\begin{array}{c}\begin{array}{c}\text { Annual cost } \\
\text { (DH) }\end{array} \\
3556080,00\end{array}$} \\
\hline & & 296340 & $(\mathrm{KG})$ & \\
\hline $\begin{array}{l}\text { Air/water heat } \\
\text { pump type } \\
\text { DRV-hydro kit } \\
\text { and solar ther- } \\
\text { mal panels }\end{array}$ & 1540 & $\begin{array}{c}1055 \\
622,42\end{array}$ & (KWh) & 1055622,42 \\
\hline
\end{tabular}

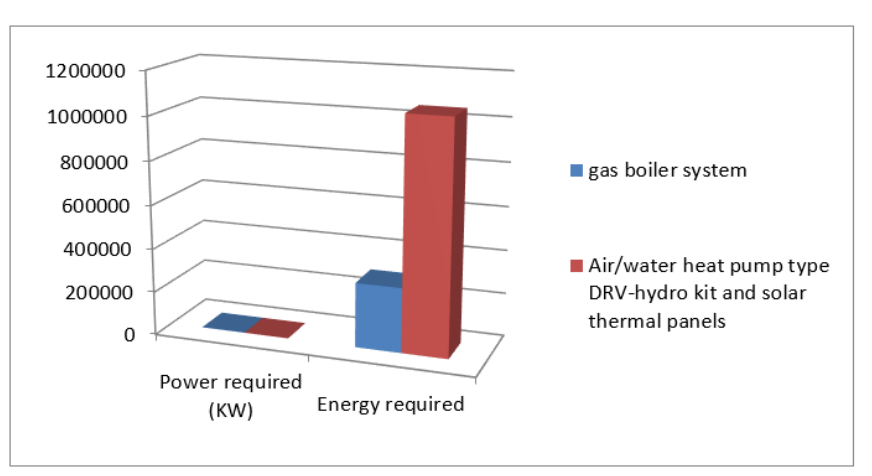

Table 2

\begin{tabular}{|l|c|c|}
\hline Amount & $\begin{array}{c}\text { Gas boiler } \\
\text { system }\end{array}$ & $\begin{array}{c}\text { Heat pump/solar } \\
\text { panel systems }\end{array}$ \\
\hline $\begin{array}{l}\text { Total annual GAS con- } \\
\text { sumption (DH) }\end{array}$ & 3556080 & 0 \\
\hline $\begin{array}{l}\text { Total annual Electricity } \\
\text { consumption (DH) }\end{array}$ & 0 & 1055622,42 \\
\hline Total annual (DH) & 3556080.00 & 1055622,42 \\
\hline Annual gain & 0 & 2500457,58 \\
\hline $\begin{array}{l}\text { Return on investment } \\
\text { (Month) }\end{array}$ & & 18 months \\
\hline
\end{tabular}
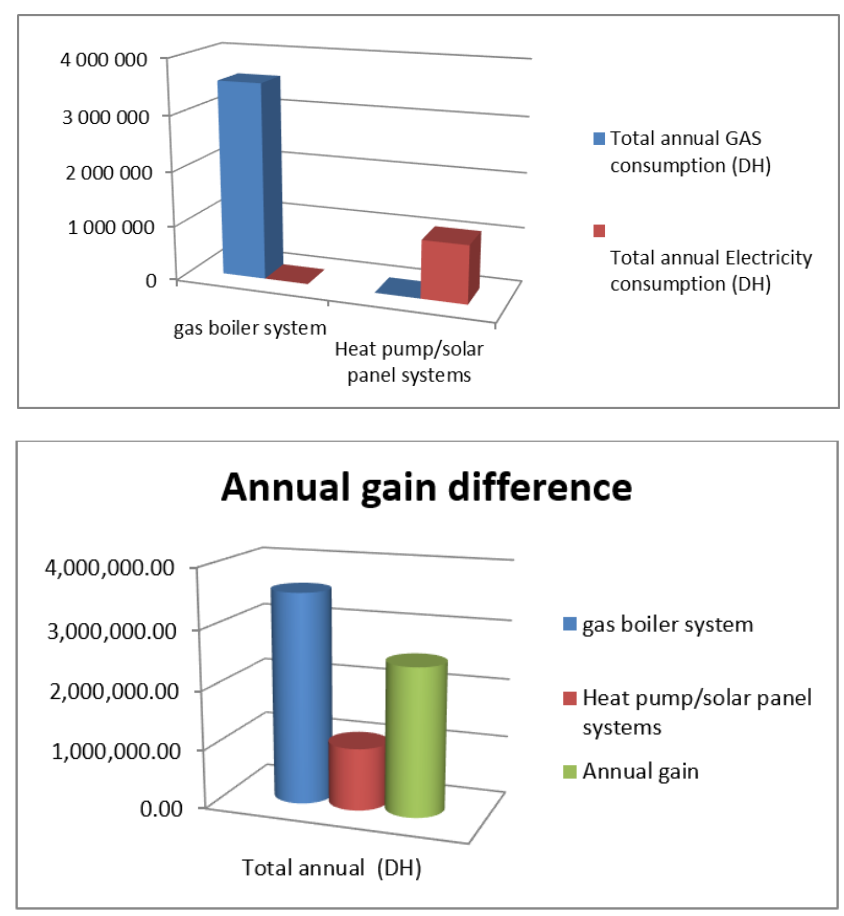

Table 3

For the $1540 \mathrm{KW}$ power requirement, the annual electricity consumption of the DRV-hydro kit and solar thermal panels solution is around $1055622.42 \mathrm{KWh}$. As electricity in Morocco costs about $1 \mathrm{Dh}$ per $\mathrm{Kw}$, the annual cost of this solution is $1055,622.42$ DHS. 
To have the annual gas consumption of the $1540 \mathrm{KW}$ boilers, we need 296340 KG of gas, with GHG emissions from combustion. The price of gas in Morocco is approximately Dhs per kilogram, so the annual cost of this solution is DHS 3556080.00(The exchange rate: $\left.1 \$ U_{s}=9 \mathrm{Dh}\right)$.

For the second solution, which combines the DRV-Hydro kit system, which operates in winter or in non-sunny periods, and the solar thermal panels, which operate in summer and in sunny periods, for the need of $1540 \mathrm{KW}$ of power, the consumption is around 1055622.42 KWh.

As electricity is approximately $1 \mathrm{Dh}$ per KW in Morocco, the annual cost of this system is $1055,622.42$ DHS.

The qualitative analysis that is based on the literature review in this study is based on information from several studies. Among these studies, we particularly mention the synthesis reports of the Intergovernmental Panel on Climate Change (IPCC).As an intergovernmental institution established by the World Meteorological Organisation (WMO) and the United Nations Environment Programme (UNEP). IPCC shows the most critical challenges posed by fossil fuels in terms of climate change and their role in greenhouse gas emissions [17].

We deduce from the comparative analysis of these two options that the environmental system is more profitable. It generated an annual gain of 2,500,457.58 Dhs [18-23].

\section{Conclusion}

- In conclusion, the DRV-hydro kit and solar thermal panel air/ water heat pump solution, using sustainable energies, is characterised by high energetic efficiency. It has many advantages over the combustion system. This solution doesn't need to use gas tanks that require a location outside the buildings, a very important logistic for the refuelling. It also avoids the need for chimneys for the exhaust of smoke and the $\mathrm{CO}_{2}$ emission.

- $\quad$ This facility will lead the way in the use of renewable energies in Morocco, and it will be a model for other sports facilities to join in this energy choice.

- $\quad$ From an economic point of view, this project is profitable, with a return on the investment over 18 months.
- Finally, and in the short term, the objective of the complex is to reach $100 \%$ sustainable energies.

- $\quad$ This will lead to HQE and Iso 14001 energy certification and will make this structure the first green sports centre in the world.

\section{Bibliography}

1. "Collectif Dunod: Développement durable au cœur de l'entreprise". Emmanuelle Reynaud, Florence Depoers, Caroline Gauthier, Jean-Pascal Gond, Grégory Schneider-Maunoury. Dunod (2011).

2. L'entreprise au cœur du développement durable: Auteurs: Laurence Lecoeur. Gereso (2010).

3. Françoise Quairel-Lanoizelée. Michel Capron: La responsabilité sociale d'entreprise. La découverte (2010).

4. La transition énergétique. Actes de la conférence, Fédération de l’Energie, Casablanca, Novembre (2013).

5. NOAA/NASA (janvier 2015) - NOAA/NASA (janvier 2016).

6. Chiffres clés du climat France et Monde (edition) (2016).

7. Organisation Météorologie Mondiale (mai) )2014).

8. Bertrand F. Changement climatique et adaptation des territoires, dans: Développement durable et territoire (Zuindeau B., ed.), Presses universitaires du Septentrion, collection environnement et société, Villeneuve d'Ascq. Selon le GIEC (2007), globalement: la température moyenne de l'atmosphère a augmenté au niveau mon (2010): 339-350.

9. Bertrand F., et al. (2012).

10. Chalas Y and Soubeyran. "Incertitude, environnement, aménagement, quelle rupture?, dans : Comment les acteurs s'arrangent avec l'incertitude?". éditions archives contemporaines (2010): 135-157.

11. Adger WN., et al. "Assessment of adaptation practices, options, constraints and capacity". Climate Change 2007: Impacts, Adaptation and Vulnerability. Contribution of Working Group II to the Fourth Assessment Report of the Intergovernmental Panel on Climate Change, M.L. Parry, O.F. Canziani, J.P. Palutikof, P.J. van der Linden and C.E. Hanson, Eds., Cambridge University Press, Cambridge, UK (2007): 717-743. 
12. Groupe d'experts intergouvernemental sur l'évolution du climat (GIEC), Bilan 2007 des changements climatiques. Contribution des Groupes de travail I, II et III au quatrième Rapport d'évaluation du Groupe d'experts intergouvernemental sur l'évolution du climat [Équipe de rédaction principale, R.K. Pachauri et A. Reisinger (publié sous la direction de )], GIEC, Genève, Suisse, 103 p.16 Pour les PCET, Cf. Art. 75 de la loi Grenelle 2; pour les SRCAE, Cf. Art. 68 de la loi Grenelle 2 (2007).

13. Brohmann B. "Sustainable Consumption as a process: the Role of Local Context". in Charter (2006).

14. Scheer H. L'autonomie énergétique. Une nouvelle politique pour les énergies renouvelables, Actes Sud (2007).

15. Laigle L. Vers des villes durables. La trajectoire de quatre agglomérations européennes (2009).

16. Jackson T. The Earthscan Reader in Sustainable Consumption, London, Earthscan. Editions PUCA, Paris (2006).

17. Rajendra K. Pachauri et col Groupe d'Experts Intergouvernemental sur l'Evolution du Climat (2015).

Webographie: http://cdurable.info/Les-entreprises-marocaineset-les-enjeux-du- developpement-durable,170.html

http://www.pnud.org.ma/Environnement.asp

http://www.oasistafilalet.ma/main.php?id=72\&cont=436

www.developpementdurable.org/

www.vedura.fr/developpement-durable/

http://www.affaires-generales.gov.ma/index.php/fr/2012-10-

08-16-53-00/les- premi\%C3\%A8res-assises-nationales-de-la-

gouvernance.html

Volume 4 Issue 12 December 2021

(C)All rights are reserved by Kharbouch Hassan., et al. 